\title{
Determinants of Investment In Islamic Crowdfunding
}

\author{
Muhamad Nafik Hadi Ryandono ${ }^{1}$, Ida Wijayanti², Kumara Adji Kusuma ${ }^{3}$ \\ ${ }^{1,2}$ Islamic Economics Department, Universitas Airlangga, Indonesia \\ ${ }^{3}$ Universitas Muhammadiyah Sidoarjo, Indonesia.
}

Submitted: 18 April 2020, Accepted: 27 June 2020, Published: 30 June 2020

\begin{abstract}
Investment decisions in Islamic Crowdfunding have many determinants, including: project quality, creator abilities, social network creators, reputation and entrepreneur experiences. This study examines the influence of significant and insignificant determinants of investment in Islamic Crowdfunding. It uses a random sampling technique with Structural Equation Modeling Partial Least Square (PLS) as the analysis model. The results show that social creators and entrepreneur experiences have a significant effect on investment in Islamic Crowdfunding. Contrastingly, project quality, creator ability, and reputation have insignificant influences. Entrepreneur experiences and reputation of the platform have dominant and least influence on investment in Islamic crowdfunding, respectively. Creator's ability has a dominant-negative effect on Islamic Crowdfunding, and therefore, it requires special attention. The sharia values contained in all investment determinants are the primary consideration by investors. Therefore, increasingly inevitable sharia compliance is a necessity from time to time
\end{abstract}

Keywords: determinant, investment, Islamic Crowdfunding, Structural Equation Modeling. 


\section{INTRODUCTION}

Triple T Technology, which means Telecommunications, Tour, and Travel, is developing rapidly, changing human life quickly and dynamically. Technological advancements have driven various activities, including economic and financial aspects. Information Technology (IT) has become a necessity in the financial sector. The development and innovation of technology-based financial services have penetrated various financial sectors throughout the world. In Fintech, financial services are very standardized and low-cost. Since it is internet-based, it is not geographically concentrated. Also, there is changing consumer behavior, less regulation of financial services, and relatively lower risks (Romanova \& Kudinska, 2016).

The rapid development of Fintech also occurred in Indonesia, both in sharia and conventional systems. For instance, there were only 88 Fintech companies in 2018 . However, the number proliferated to 161 by February 2020. Moreover, the number of Fintech sharia companies increased by 4, from 9 to 13. In 2018, conventional Fintech companies were 79 and grew to 149 in February 2020. Although Fintech companies did not grow rapidly, there was a significant rise in the number of lender accounts, borrower accounts, loan disbursements, and total assets between 2017 and February 2020. The rapid development of Fintech-based business is attractive to both domestic and foreign investors. Data on the development and growth of Fintech companies in Indonesia is shown in Table 1.

Table 1. Developments in Indonesia Fintech 2017- February 2020

\begin{tabular}{|c|c|c|c|c|c|}
\hline No & Information & 2017 & 2018 & 2019 & Feb. 2020 \\
\hline 1 & $\begin{array}{l}\text { Number of Lender } \\
\text { Accounts (Entities) }\end{array}$ & & & & \\
\hline & a. Java & 75,769 & 155,230 & 500,030 & 520,172 \\
\hline & b. Outside Java & 24,028 & 50281 & 102,149 & 106,021 \\
\hline & c. Overseas & 1,143 & 1996 & 3,756 & 3,810 \\
\hline & Total & 100,940 & 207.507 & 605,935 & 630,003 \\
\hline 2 & $\begin{array}{l}\text { Number of Borrower } \\
\text { Accounts (Entities) }\end{array}$ & & & & \\
\hline & a. Java & 237,319 & $3,664,645$ & $15,397,251$ & $18,403,371$ \\
\hline & b. Outside Java & 22,316 & 694,803 & $3,171,872$ & $3,907,082$ \\
\hline & Total & 259,635 & $4,359,448$ & $18,569,123$ & $22,327,795$ \\
\hline 3 & $\begin{array}{l}\text { Loan Distribution (Rp. } \\
\text { Billion) }\end{array}$ & & & & \\
\hline & a. Java & $2,186.63$ & $19,177.46$ & $69,823.52$ & $81,633.84$ \\
\hline & b. Outside Java & 378.32 & $3,048.61$ & $11,673.99$ & $13,760.73$ \\
\hline & Total & $2,564.95$ & $22,666.07$ & $81,497.1$ & $95,394.57$ \\
\hline 4 & Financier & & & & \\
\hline & a. PMDN & - & - & 113 & 110 \\
\hline & b. PMA & - & - & 51 & 51 \\
\hline & Total & & & 164 & 161 \\
\hline 5 & Assets (Rp. Billion) & & & & \\
\hline
\end{tabular}




\begin{tabular}{llrrr}
\hline a. Conventional & - & - & $2,985.65$ & $3,337.76$ \\
\hline b. Sharia & - & - & 50.62 & 46.70 \\
\hline Total & & & $3,036.26$ & $3,384.46$ \\
\hline $7 \quad$ Operational System & & & & 149 \\
\hline a. Conventional & - & 79 & 152 & 13 \\
\hline b. Sharia & - & 9 & 12 & 162 \\
\hline Total & - & 88 & 164 & 104 \\
\hline
\end{tabular}

Source: Financial Services Authority (OJK, 2017- February 2020) and various sources.

Table 1 shows that Fintech companies are conducting their business activities as investment intermediaries and managers. Therefore, Fintech companies are profit-oriented and channel lender funds to the borrower by withdrawing loan costs (financing). The yield for conventional Fintech is generally in the form of loan interest, while sharia yield depends on the contract. The sharia contract on partnership or syirkah includes mudharabah and musyarakah contracts. The sale contracts include mudarabah, salam, and istisna, while ijarah is a lease contract. The cost of these contracts consist of margin and rental and intermediary fees. The income received by Fintech from its borrowers is distributed to lenders or investors based on the terms of the contract. The funds channelled by Fintech companies are from its founders and lenders. Therefore, these Fintech companies can be categorized as crowdfunding institutions. According to Ryandono (2018), Fintech has been widely adopted by the conventional financial industry and Islamic finance. This system has also begun to be adopted by philanthropic activities in crowdfunding and financing by targeting small funds which have been inefficient. Crowdfunding institutions widely apply this digitalization model with a fintech platform engaged for philanthropic purposes, specifically the Zakat, Infaq, Sadaqah, and Waqaf (Laziswaf) institutions, as well as other institutions not bound by certain religions.

According to Hendratmi, Sukmaningrum, Ryandono, and Ratnasari (2019), the Islamic financial industry also penetrated investment mechanisms in the form of a crowdfunding platform to fund productive investments. Islamic Crowdfunding is implemented based on sharia principles for funding halal projects and products permitted by Islamic Law. According to Hendratmi, Ryandono, and Sukmaningrum (2019), Islamic crowdfunding is expanded to include donation agreements (grants and qardh), equity-based syirkah (Mudharabah and musyarakah) with profit sharing systems, debt financing such as murabahah, salam, and ishtisna (costs plus profit margins), and ijarah or rent. Therefore, crowdfunding has adopted the Islam teachings to ensure that assets do not only revolve among rich people, as mentioned in the Qur'an's SurahAl-Hashr verse 7:

"What are the spoils (fa'i that Allah gave to His Messenger (who are)) from the inhabitants of several lands, are for Allah, Rasul, relatives (Rasul), orphans, poor people and for people on their way "So that the treasure should not only circulate among rich people among you. What the Apostle gave you, accept it. And what he forbids you, leave it. And fear Allah. Indeed, Allah is very harsh in his punishment." 
Kshetri (2017) stated that crowdfunding has vital implications for entrepreneurial activities and therefore needs more attention and research. Research from the World Bank (2013) shows that crowdfunding business is increasingly spread out in various parts of the world with a variety of funding patterns depending on its objectives and investment methods. According to Bi, Liu, and Usman (2017), the complexity of business processes and risk of crowdfunding in lending and equity is quite significant (Hemer, 2011; Joenssen, Michaelis, \& Müllerleile, 2014). In some lending and equity crowdfunding platforms, online business feasibility services to investors are provided.

\section{Determinants of Investment in Crowdfunding}

Although crowdfunding is a new concept, its basic idea is old fashioned. The presence of crowdfunding was present in different forms and styles. For instance, in the late middle ages, there were systems of benevolent fundraising and micro-finance (Bremner, 1996; Ingenhoff \& Koelling, 2009; Morduch, 1999). Due to the advancement in communication and information technology, a system of collecting funds from many people in different models is modified and changed. In the digital finance era, crowdfunding is a general term relating to the collection of funds from communities both for social and business purposes. In this era, crowdfunding is a process of raising funds for the community to finance activities using Financial Technology (Fintech) system. Golic (2014) argues that crowdfunding is a result of social media and requires close collaboration between the three participating parties: entrepreneurs or funded business managers, investors, and intermediaries. Each party has a mission that unites them to achieve desired goals.

Investors, or "crowdfunders", gather as a large group of members of the general public. This might be ordinary people without the competence of professional investors. Crowdfunders recognize the potential of a project or consider certain promising ideas, and therefore they each invest small financial resources. They receive non-financial benefits or financial compensation for their contributions. Prizes for investors in crowdfunding can be in form of social returns, products or services, financial returns or refunds (De Buysere, Gajda, Kleverlaan, \& Marom, 2012).

The crowdfunding platform is a virtual electronic intermediary between entrepreneurs and investors, where all communication and fundraising take place. It facilitates the process of transferring funds from those desiring to contribute or invest in need of capital. The platform operates by allowing those seeking funding to pitch on site to outline how much money they need, what they need it for and what investors receive in return for contributions. Potential funders can then see the offer on the platform, interact with those looking for finance and other potential funders and make investment decisions. 
The parties that might need crowdfunding include business entities in various sectors. Managers create an attractive portfolio for business ideas spread on the internet to attract investors with visions and motivations in the same field. The manager is responsible for managing the funds invested in them.

Mollick and Kuppuswamy (2014) argue that two main factors influence investment with the crowdfunding model: a private network of crowdfunding managers and quality of projects being funded. According to Zheng, $\mathrm{Li}, \mathrm{Wu}$ and $\mathrm{Xu}$ (2014), entrepreneurial social networking has a significant positive effect on crowdfunding performance in China and the United States. Bi, Liu, and Usman (2017), established that clarity of relevant information about projects delivered via video and the "Like" count of a project directly influenced investors' funding decisions compared to E-word of Mouth. Perceived product creativity is positively related to crowdfunding performance, both directly and indirectly, through affective reactions from potential funders. Ho, Lin, and Lu (2014) proved that perceived value has a significant influence on supporting funding intentions. From Zhao, Chen, Wang, and Chen (2017), commitment and perceived risk positively influence supporting funding intentions. Apart from website design, the essence of projects such as product quality, product innovation, and managers' ability positively influence intention to invest in crowdfunding (Wang \& Yang, 2019). Seetharaman, Niranjan, Patwa, and Kejriwal (2017) stated that investors' knowledge and experience in the capital market, such as gains or losses in stocks, affect future investment decisions. To invest, investors consider project quality, creator ability, crowdfunding platform reputation, social network, and entrepreneurship experience.

\section{Project Quality}

Crowdfunding can be implemented as an alternative funding source for project initiators, including startups not eligible for loans (Wahjono, Marina, \& Widayat, 2016). The quality of the project funded is a crucial factor assessed by investors before making investment decisions. The attractive aspects include the uniqueness of crowdfunding in attracting investors, clarity of information about products, risks, and benefits obtained. The Project Value promoted by crowdfunding is critical for crowdfunders' decisions because they have different motivations from traditional financial investors.

According to Lehner (2013), Crowd investors usually focus on a company's core ideas and values rather than guarantees. Lindenberg and Steg (2007) established that a crowd of investors could be considered motivated by altruistic or normative reasons, including meeting their moral or ethical norms, and choosing social ideas deemed appropriate and necessary (Lehner, 2013). Lam and Law (2016) stated that investors mix financial profits with their noneconomic goals, can be willing to forget about financial returns and achieve social benefits. 
According to De Buysere et al. (2012), there are three types of motivation for individuals involved in crowdfunding: social returns, material acquisition, and monetary rewards. Crowdfunders participate in donation, or reward-based crowdfunding motivated by altruistic motives arising from their sense of belonging in community or project results. In the loan-based or equity-based model, investors are mainly motivated by the prospect of financial returns '(Wijayanti, Herianingrum, \& Ryandono, 2020).

Information describing projects on a crowdfunding platform has a significant impact on investors awareness (Mudambi \& Schuff, 2010). The more detailed the description, the more useful they are in decision making (Cheung, Lee, \& Rabjohn, 2008). When founders upload specific information about calculations or how to raise money used, a project becomes more transparent and attractive to crowdfunders. It helps build trust and encourages people to provide comments and feedback about products (or services) and share their ideas regarding the effective use of capital (Tu, Anh, \& Thu, 2018).

Project Risk refers to customer's perception of the possibility of negative consequences after obtaining an object, or level of loss felt subjective (Featherman \& Pavlou, 2003). Amaro and Duarte (2015) stated that online transactions are more likely to cause uncertainty, hence considered riskier than traditional trade. Previous studies established that perceived risk is a significant determinant of consumer behaviour (e.g., Cho, Bonn, \& Kang, 2014; Featherman \& Pavlou, 2003). For example, Cho et al. (2014) stated that perceived risk harms online repurchase intentions for wine, while attributes related to sensory and wine origin attributes influence their repurchase intentions through perceived risk. In case crowdfunders perceive that they may gain product-related knowledge, make new friends, gain financial benefits, or experience excitement in crowdfunding projects, they increase their connections and commitments (Zhao, et al. 2017). Therefore, this study concludes that the perceived benefits of crowdfunders cause higher investment intentions. Therefore, the quality of the project influences investment in Islamic Crowdfunding.

\section{Crowdfunding Platform Reputation}

Investors consider business traction when investing in crowdfunding. They examine whether crowdfunding can be trusted to provide results of investment as expected. Also, they assess whether crowdfunding can be trusted with its financial statements and performance. It is imperative to determine the role of social media in the crowdfunding platform. Gerber, Hui, and Kuo (2012), established that creators are motivated to participate in raising funds, accepting validation, connecting with others, imitating successful experiences, and expanding awareness of work through social media. 
Online reviews on crowdfunding are the most effective marketing tools because people's online behaviour can be significantly influenced by word of mouth. Moreover, electronics and online shoppers rely heavily on online product reviews to make purchase decisions (Park \& Kim, 2008; Schlosser, 2011; Sen \& Lerman: 2007). Consumers always assess online product reviews using ratings, text ranking congruence, sources, number of "Likes," and overall positive and negative reviews (Benedicktus, Brady, Darke, \& Voorhees, 2010; Pan \& Zhang, 2011; Schlosser, 2011). In general, previous literature shows that word of mouth has a significant effect on online behaviour. More online reviews and "Like" counts for Project-based crowdfunding prizes attract investments (Bi et al., 2017).

\section{Creator Ability}

All internal and external resources and business management skills help complete project plans. Highly capable managers give supporters the impression that they can complete what they promised. In case managers cannot show resources and skills, supporters may doubt whether the project can be completed and may not have a strong desire to offer support. From an entrepreneurial perspective, investors also prefer to invest in projects with entrepreneurial selfefficacy, desires, and business creation abilities. Therefore, to attract more supporters, project managers should provide more information about their resources and abilities. Crowdfunding Managers' ability influences the intention to invest in crowdfunding.

\section{Social Networks and Entrepreneurial Experience of Investors}

Powers (2012), described crowdfunding as "a financial mechanism that allows startup companies to raise funds from the general public through website intermediaries. This is an open call, basically over the internet, for provision of financial resources either in the form of donations or gifts and voting rights to support initiatives for specific purposes" (Belleflamme, Lambert, \& Schwienbacher, 2010). Projects and businesses are funded by a collection of contributions from many individuals, enabling innovators, entrepreneurs and business startups to use their social networks to raise capital (De Buysere et al., 2012).

Crowdfunders are motivated to participate in finding prizes, support creators and goals, and strengthen connections with people on social networks (Bi et al., 2017). According to previous literature, investment intentions or funding success are significantly influenced by project quality signals such as readiness, narratives, and decisions of other people's contributions. Individual quality signals, such as personal characteristics, credit eligibility and social networking, are also imperative (Mollick \& Kuppuswamy, 2014). The social network of crowdfunding managers influences intention to invest in Islamic Crowdfunding. The business and experience of investors affect investment intentions. Experienced investors can be more precise and confident when finding the right investment project. 
The determinants of investment in crowdfunding include Project Quality, Reputation, Creator Ability, Creator Social Networks, and Investor Entrepreneur Experiences. This study focuses on whether determinants of investment in crowdfunding also apply to crowdfund whose operations are based on Islamic sharia principles. In Islamic Crowdfunding, implementation and compliance of sharia are considered by investors when making decisions. The conceptual framework of investment determinants in crowdfunding in Islamic perspective is shown in Figure 1.

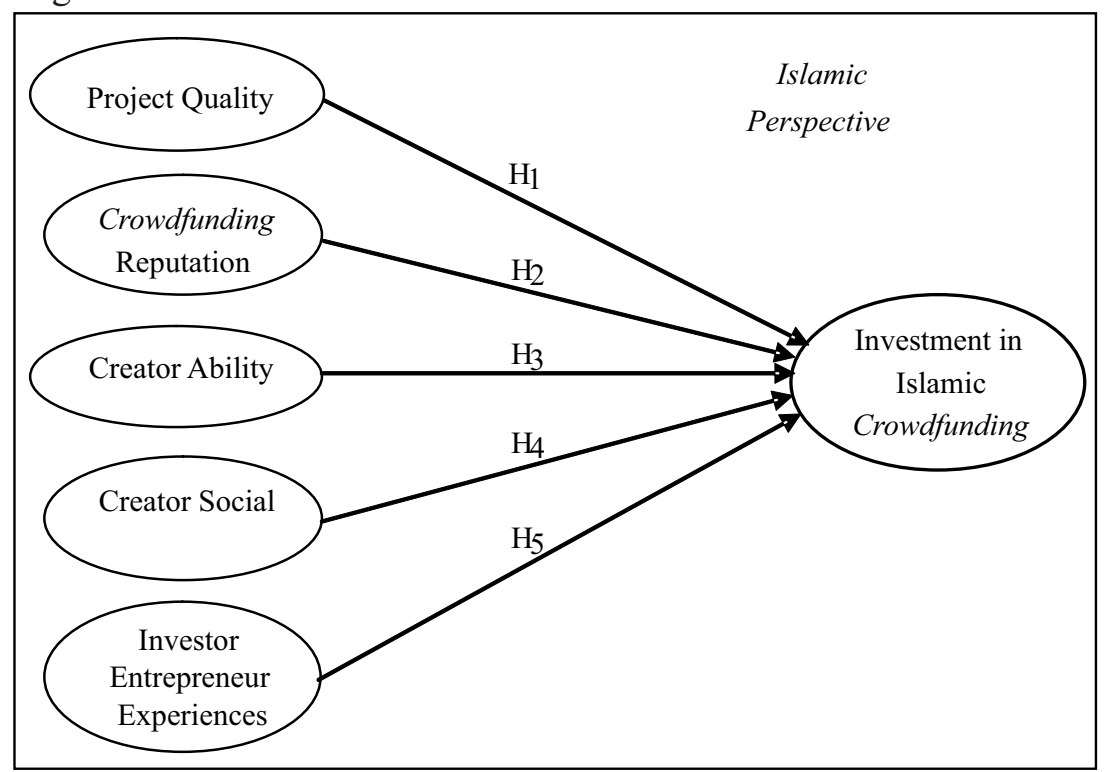

Figure 1. Conceptual framework of determinants of investing in crowdfunding

A total of 5 hypotheses were formulated and tested: a. Project quality affects investment in Islamic Crowdfunding, b. Crowdfunding Reputation affects investment in Islamic Crowdfunding, c. Creator ability influences investment in Islamic Crowdfunding, $d$. Creator social networks influence investment in Islamic Crowdfunding, e. Investor Entrepreneurial experiences influence investment in Islamic Crowdfunding

\section{METHOD}

This research uses a quantitative method with an exploratory approach. The primary data is collected using questionnaires and supported by secondary data, including the internet, OJK website, literature review and previous research. The variables are classified into two: exogenous and endogenous. Variables include Project Quality, Crowdfunding Reputation, Creator Ability, Creator Social Networks, and Investor Entrepreneurial Experiences and endogenous variables are investments in Islamic Crowdfunding.

The sampling technique is random, and data collection was based on an online questionnaire answered by respondents. Inclusion criteria include: college student taking 
diploma, bachelor, and magister with an idea of crowdfunding. The data scale is a Likert scale with a score interval between 1 to 5. (scale 1: "strongly disagree", 2: "disagree", 3: "neither agree nor disagree", 4: "agree", and 5: "strongly agree"). From 75 questionnaires collected, 71 met criteria for validity and reliability. The analysis model is Structural Equation Modeling Partial Least Square (SEM-PLS). Application of analysis SmartPLS version 3.0. SEM-PLS model was chosen since the study explores and develops existing crowdfunding concepts and theories.

\section{RESULTS AND DISCUSSION Islamic Crowdfunding}

Crowdfunding is an alternative funding model for profit-oriented and non-profit organizations, though individuals can also be financed. This model is growing rapidly with the support of information technology, specifically Financial Technology (FinTech). Arolas and de-Guevara (2012) defined crowdfunding as an opportunity for small businesses and entrepreneurs to succeed. According to Ahsien and Purnamasari (2016), crowdfunding is a practice of fundraising or investing by utilizing a website to attract public attention.

Crowdfunding was initially developed to provide personal loans, though initial investments were also financed privately (Bone \& Baeck, 2016). The process itself is marked by the success of interaction between platforms, various founding campaigns that seek financial support for their ideas and efforts, and a wide crowd interested in investing, promising, lending, or contributing ideas (Nielsen, 2018). The success of funds often depends on foreigners' willingness to support other foreigners for goals, products, or services not realized, and for which they have little direct supervision or control. However, crowdfunding has emerged as a source of finance for entrepreneurial projects (Sorenson, Assenova, Li, Boada, \& Fleming, 2016).

Bi et al. (2017) stated that the concept of crowdfunding originates from crowdsourcing, which refers to using the crowd to get ideas, feedback, and solutions to develop company activities. De Buysere et al. (2012) defined it as a collective effort of many individuals who build networks and gather their resources to support efforts initiated by other people. Hemer (2011) argued that categorization of four main types of crowdfunding, including donation-based, reward-based, loans, and equity, is based on the kind of investment that investors accept for their contributions, legal complexity, and level of asymmetric information between project creator and investors.

The United Nations Development Program (UNDP, 2017) classifies four crowdfunding models: 1). Equity: funders own the equity (shares) of projects undertaken by the crowdfunding platform, 2). Donation-based: fundraisers and funder do not expect returns 
because the goal is non-profit, 3. Crowdfunding rewards: donors provide funds hoping to receive rewards in the form of gifts, products or services from startup companies but not in the form of refunds, 4). Debt: also called Peer to Peer Lending (P2P).

Crowdfunding developments, in the beginning, were mostly based on conventional financial systems that provide returns to funders in the form of interest. Interest in Islamic economics is one of the forms of usury practices that are strictly forbidden in Islam, as mentioned in Surah Al Baqarah verse 275:

"People who take usury... are possessed by shaitan because of the pressure of insanity.

This is because they say that buying and selling are the same as usury. Allah has allowed buying and selling and forbidden usury. Anyone who gets a warning from his Lord then stops, then what he has obtained first becomes his and his affairs (it's up to) to God. Whoever repeats, they are the inhabitants of hell, they are eternal within. "(QS 2 A1 Baqarah: 275)

Many people are interested in becoming partners either as investors or financing customers from crowdfunding. This condition inspired practitioners and academics of Islamic economics to develop a crowdfunding system based on Islamic principles. In Islamic crowdfunding, operations are based on Islamic sharia principles and omit create benefits for the achievement of Islamic sharia objectives (maqashid sharia). Maqashid sharia in question is the protection of religion (ad dien), soul (an nafs), aqal (al Aql), descendants (an Nasl) and property (al Maal).

Hendratmi et al. (2019), believe that Islamic crowdfunding platform is an Islamicbased system that funds halal projects and products permitted by Islamic Law, and products and funds. The concept of crowdfunding Islam is almost the same as the concept of crowdfunding in general. The difference lies in the application of supported asset transaction mechanisms and profit loss margins (Marzban, Asutay, \& Boseli, 2014). Based on various sources, crowdfunding models based on Islamic sharia principles are shown in Table 2.

Table 2. Islamic Crowdfunding Instruments and Models

\begin{tabular}{|c|c|c|c|}
\hline $\begin{array}{l}\text { Financing } \\
\text { Objectives }\end{array}$ & Crowdfunding Model & Form of Potential Entities & Contract Instruments \\
\hline Islamic Charity & Donation Based & $\begin{array}{l}\text { Microfinance Institution, mustahiq, } \\
\text { Islamic Social Institution }\end{array}$ & $\begin{array}{l}\text { Grant, Qardhul Hasan, qard, zakat, } \\
\text { infaq, sadaqah and waqaf }\end{array}$ \\
\hline Product & Reward-Based & $\begin{array}{l}\text { Microfinance Institution, MICRO, } \\
\text { and Small Business, Startup Business }\end{array}$ & Buy and Sell / Bay' \\
\hline \multirow[t]{5}{*}{ Investment } & Debt Based & a. Microfinance Institution & \multirow{4}{*}{$\begin{array}{l}\text { Single contract: Principles of sale and } \\
\text { purchase (Murabaha, salam, istishna'), } \\
\text { Principle of Lease (Ijarah). } \\
\text { Many Investors: sukuk (Principles of } \\
\text { Sale and Purchase (Murabaha, salam, } \\
\text { istishna'), Rental Principles (Ijarah) } \\
\text { and multi-sukuk }\end{array}$} \\
\hline & & b. Micro and Small Busines & \\
\hline & & $\begin{array}{l}\text { c. Sharia Business- } \\
\text { Cooperative Cooperative }\end{array}$ & \\
\hline & & d. Baitul Maal wat Tamwil & \\
\hline & Equity-Based & $\begin{array}{l}\text { Micro and Small Business (small } \\
\text { enterprises), Startup Business } \\
\text { Mustahiq and Nadzir }\end{array}$ & $\begin{array}{l}\text { Single contract: Syirkah principle } \\
\text { (Mudharabah and musyarakah) } \\
\text { Many Investors: Sukuk Mudharabah, } \\
\text { musyarakah sukuk and multi sukuk }\end{array}$ \\
\hline
\end{tabular}

Source: Formulation from Various Sources 
According to Biancone and Secinaro (2016), crowdfunding and Islamic finance have the same concept, specifically investors. Both have the potential to invest together with high returns to create fairness in the distribution of results. Taha and Macias (2014) also Hasan and Dounia (2013) established that crowdfunding and Islamic finance are inherently compatible since they have the same characteristics. Marzban et al. (2014) stated that in Islamic crowdfunding criteria, there must be a Sharia Supervisory Board (DPS). Revenue is obtained from halal sources and does not contain usury.

Islamic Crowdfunding (IC) is different from conventional ones in different aspects including; structure, investment, returns, bank partners, zakat and operational principles. Islamic Crowdfunding organizations must have a Sharia Supervisory Board ensures adherence to Islamic principles and have veto rights in the implementation of sharia in crowdfunding management. Investment may only be lawful business and cannot be involved in ribawi, gharar, taghrir, maisir and other activities prohibited in Islam. Furthermore, investment return adjusted business contract is chosen, while conventional approach generally uses interest. In Islam, interest is a form of usury forbidden and must be avoided. When it comes to bank partners, Islamic Crowdfunding requires partnering with Islamic banks. When forced, then Islamic banks must be dominant both in number of partners and funds placed. Conventional approach may partner with Islamic or conventional banks without Islamic bank regulations. Islamic Crowdfunding is obligatory, but zakat is not obligatory even when profit reaches the proportion of zakat. In aspect of operational principle, Islamic Crowdfunding should always prioritize maqashid sharia in all its organizational activities. In contrast, conventional does not suggest promoting maqashid sharia in its operations. Figure 2 shows the operational mechanism.

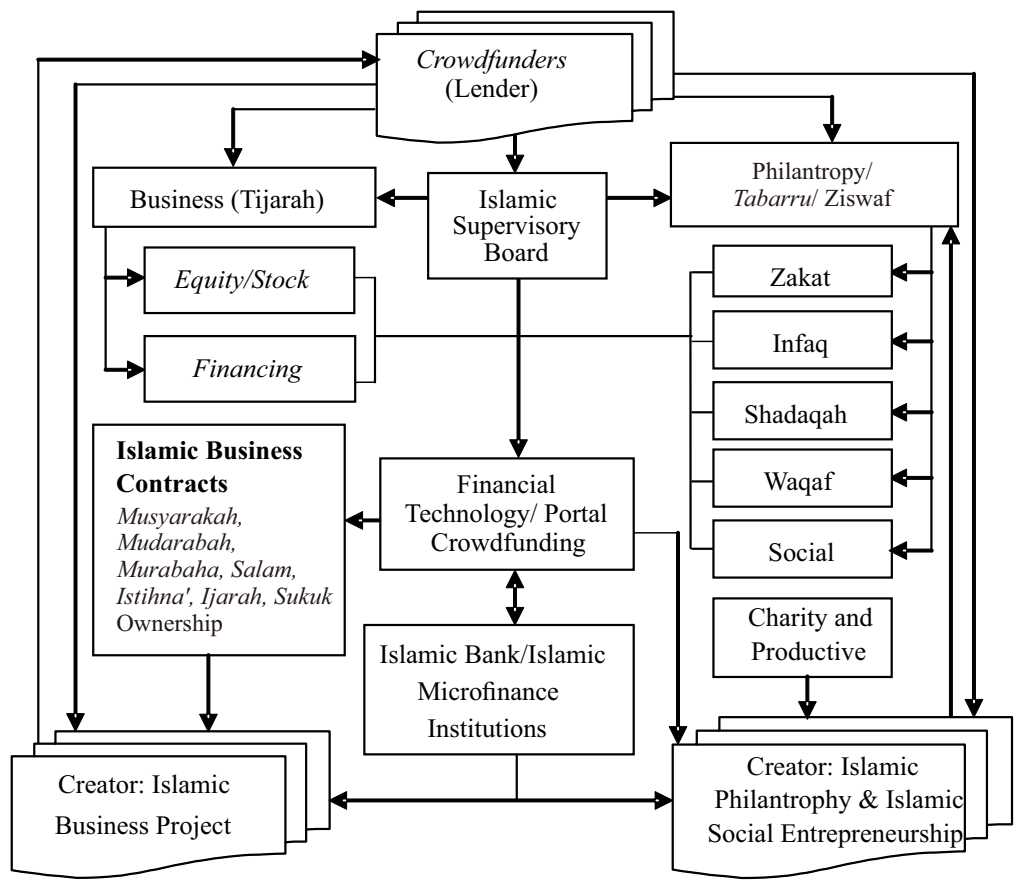

Figure 2. Mechanism of Islamic Crowdfunding 


\section{Determinants of Investment in Islamic Crowdfunding}

Investments in Islamic Crowdfunding are generally influenced by determinants such as Project Quality, Reputation, Creator Ability, Social Networks, and Investor Entrepreneur Experiences. The difference lies in an indicator measuring determinant, specifically sharia perspective.

Project quality is based on values, ideas, and business social benefits based on Islamic ethics. The focus is on the desired business uniqueness value, clarity of information about products, business risks and projects, halal revenue information, and project risk of operationalization.

The reputation of crowdfunding platforms is based on transparent and accountable financial statements, accurate business performance reports, information from person to person, and compliance with implementation. Creator ability is determined by security, honesty, and stability of Human Resources (HR), the professionalism of management of sharia business, ability to manage resources, the ability of Islamic entrepreneurs and business efficiency.

Social network creators are measured by the ability to build Islamic social networks (ta'awun), the marketing concept is based on sharia marketing, always building ukhuwah Islamiyah (Islamic brotherhood) and the strength of sharia business partners networks.

Business experience is measured by the real experience of investors in the business and their understanding of investors about sharia business. It involves investor experience in previous sharia and non-sharia investments.

Crowdfunding has become an alternative source of public funding, especially for MSMEs and lower-class individuals. SEM-PLS requires validity (indicator) tests to confirm whether a construct is a valid or invalid gauge. Testing validity and trust of data involve matching the loading factor number of each indicator in the underlying construct that should be above 0.50 (Hair, Black, Babin, \& Anderson, 2010). Also, the Average Variance Extracted Figures (AVE) for each construct should be above the recommended minimum value of 0.50 . The results of the analysis show that the loading factor of each construct and AVE value is above the required standard. The convergent validity measurement model has given satisfactory results, and therefore, the valid indicator is a measure.

The next requirement is a reliability test, which involves determining consistency between item values shown by Cronbach's alpha coefficient. According to Fornell and Larcker (1981), Cronbach's alpha numbers from data assessed for internal consistency are categorized as reliable, in case composite reliability has a minimum value of 0.70 . The results of analysis produce that; all Cronbach's alpha values range from 0.854 to 0.1000 . Therefore, the indicator is a reliable measurement. 
In case the testing result on validity and reliability have met requirements, the effect of exogenous variables on endogenous variables is analyzed. Table 3 shows the results of SEMPLS model analysis.

Table 3. PLS Analysis Results

\begin{tabular}{llcccccc}
\hline No & $\begin{array}{l}\text { Effect of Exogenous Variables } \\
\text { on Endogenous }\end{array}$ & $\begin{array}{c}\text { Original } \\
\text { Samples }(\mathrm{O} \\
/ B\end{array}$ & $\begin{array}{c}\text { Sample } \\
\text { Mean (M) }\end{array}$ & $\begin{array}{c}\text { Standard } \\
\text { Deviation }\end{array}$ & $\begin{array}{c}\mathrm{T} \\
\text { Statistics }\end{array}$ & $\begin{array}{c}P \text { - } \\
\text { value }\end{array}$ & $\begin{array}{c}\text { Supported/ } \\
\text { Not } \\
\text { Supported }\end{array}$ \\
\hline 1 & $\begin{array}{l}\text { Project Quality Against Investment } \\
\text { in Islamic Crowdfunding } \\
\text { Crowdfunding Reputation on } \\
\text { Investment in }\end{array}$ & 0.150 & 0.139 & 0.192 & 0.781 & 0.435 & $\begin{array}{c}\text { Not } \\
\text { Supported }\end{array}$ \\
$\quad \begin{array}{l}\text { Islamic Crowdfunding } \\
\text { Creator Ability Against Investment } \\
\text { in Islamic Crowdfunding } \\
\text { Social Network Creator Against }\end{array}$ & -0.159 & -0.126 & 0.187 & 0.851 & 0.395 & $\begin{array}{c}\text { Not } \\
\text { Investment in }\end{array}$ \\
$\begin{array}{l}\text { Islamic Crowdfunding } \\
\text { Entrepreneurial Experiences } \\
\text { Against Investment in } \\
\text { Islamic Crowdfunding }\end{array}$ & 0.326 & 0.325 & 0.114 & 2.865 & 0.004 & Supported \\
\hline Sourted
\end{tabular}

Source: Data Analysis

The analysis result shows that exogenous variables with significant influence (P-value $<0.05$ ) on investment in Islamic crowdfunding are two, include social network creator and entrepreneur experiences. However, three other exogenous variables have an insignificant effect $(\mathrm{P}$ value $>0.05)$ on Islamic crowdfunding, specifically project quality, crowdfunding reputation, and creator ability. Entrepreneur experiences (B: 0.356) have a dominant impact, while reputation has the least influence (B: 0.137). The creator ability hurts investment in Islamic Crowdfunding (B: -0.159). Five determinants of investments in Islamic crowdfunding simultaneously have a significant effect on investments in Islamic Crowdfunding and the ability to explain variation by $35 \%$ (R square: 0.35 ).

The Quality of Projects were determined based on various criteria, including: ideas and business social benefits based on Islamic business ethics as desired business uniqueness values, clarity of information about products and projects, halal revenue information, and project not under sharia principles with insignificant influence of 0.150 . This is shown by probability value greater than $5 \%$ (P-value; $0.435>0.05)$. These findings are different from previous research, which proved the effect of product quality on investor investment behaviour (Wang \& Yang, 2019). However, introduction and literacy to the public have not been maximized, even though it is a dominant construct of a Quality Project. Therefore, literacy about the perception of sharia business in crowdfunding should be improved in a structured, systematic and massive manner for the public understanding and investment interest in crowdfunding to increase.

The reputation of the platform has an insignificant effect of 0.137 on investment in Islamic Crowdfunding. This is because P-value is greater than 0.05 , which is equal to 0.466 . This contravenes Bi's research (2019), which stated that the reputation of crowdfunding is represented by the level of customer's e-word of mouth on crowdfunding platform have significant influence on investors' investment intentions. The results are significantly 
influenced by the unfamiliarity of Islamic crowdfunding by the investor community.

The creator ability determined by security, honesty, and stability of Human Resources, the professionalism of sharia business management, ability to manage resources owned (tangible and intangible assets), entrepreneur ability and business efficiency, have a partial influence coefficient of -0.159 and a P-value of 0.395 . This shows that creator's ability has an insignificant negative impact on investment in Islamic Crowdfunding. This shows that investors do not believe in the ability of crowdfunding to create and manage projects to be funded. They doubt crowdfunding's to create and choose genuinely sharia-compliant projects. This is reasonable because there is still minimal literacy for investors about Islamic crowdfunding. This finding is different from some previous studies which established that the ability of owners and quality of project and innovation have a significant impact on investment intentions (Wang \& Yang, 2019). Social network creators, determined by the ability to build Islamic social networks, marketing based on sharia business, willingness to build ukhuwah Islamiyah and strength of business partner networks, significantly influence investment decision (P: 0.004 ) by 0.326 . This result shows that investors firmly believe that Islamic Crowdfunding has a comprehensive and strong social network and sharia business partners. Social network creators are determinants easily seen and felt by investors, both empirically and through social media. They are relevant in case they are significant determinants of investing in Islamic Crowdfunding. This in line with previous studies, which established that private social network of managers influences the success in managing projects (Mollick \& Kuppuswamy, 2014).

Entrepreneur experiences, determined by the real experience of investors in business and understanding of investors about sharia business, as well as sharia and non-sharia investments, are dominant determinants with a coefficient of influence 0.356 . This shows the determinant has a significant influence on investors in Islamic Crowdfunding (P-value: 0.001). The determinant is the dominant determinant on investment. This is in line with Seetharaman et al, (2017), which showed that investor behaviour and experience have a significant influence on investment choices in crowdfunding portfolios.

In general, sharia values contained in all investment determinants in Islamic Crowdfunding are expected uniqueness and forms primary consideration by investors. This finding indicates that the public and investors have increased awareness in choosing investments following sharia principles. 


\section{CONCLUSION}

The investment determinants with significant influence on investment in Islamic Crowdfunding include social network creators and entrepreneur experiences. Project quality, creator abilities, and crowdfunding reputation have insignificant influence. Entrepreneur experiences are most dominant determinants while Crowdfunding Reputation has the least impact. Creator ability is the only determinant of investment in Islamic Crowdfunding that has a negative influence, and therefore, it requires special attention. Sharia values contained in all investment determinants in Islamic Crowdfunding are main uniqueness considered by investors. This means sharia compliance is increasingly inevitable for Islamic Crowdfunding.

The results of this study provide practical implications that Islamic Crowdfunding is a relatively new business entity that requires structured, systematic, and massive socialization and literacy. It is imperative to increase people's understanding about investing to enhance interest in investing and utilizing services. In case socialization and literacy are optimum, the determinants of investment in Islamic Crowdfunding may have significant positive impacts.

\section{BIBLIOGRAPHY}

Ahsien, I. H., \& Purnamasari, D. I. (2016). Islamic Crowdfunding as The Next Financial Innovation in Islamic Finance: Potential and Anticipated Regulation in Indonesia. European Journal of Islamic Finance, 5(5). https://doi.org/10.13135/2421-2172/1771.

Amaro, S., \& Duarte, P. (2015). An Integrative Model of Consumers' Intentions to Purchase Travel Online. Tourism Management, 46, 64-79. http://dx.doi.org/10.1016/j.tourman. 2014.06.006.

Arolas, E. E., \& de-Guevara, F. G. L. (2013). Towards an Integrated Crowdsourcing Definition. Journal of Information Science, 38 (2) 189-200 https://doi.org/10.1177\%2F01655515 12437638.

Belleflamme, P., Lambert, T., \& Schwienbacher,A. (2010). Crowdfunding: An industrial organization perspective. Prepared for the workshop Digital Business Models: Understanding Strategies', 1-31.

Benedicktus, R. L., Brady, M. K., Darke, P. R., \& Voorhees, C. M. (2010). Conveying Trustworthiness to Online Consumers: Reactions to Consensus, Physical Store Presence, Brand Familiarity, and Generalized Suspicion. Journal of Retailing, 86(4), 322-335. doi:10.1016/j.jretai.2010.04.002.

Bi, S., Liu, Z., \& Usman, K. (2017). The Influence of Online Information on Investing Decisions of Reward-based Crowdfunding. Journal of Business Research, 71, 10-18. https://doi.org/10.1016/j.jbusres.2016.10.001.

Biancone, P. P., \& Secinaro, S. (2016). The Equity Crowdfunding Italy: A Model Sharia Compliant. European Journal of Islamic Finance, 5. https://doi.org/10.13135/2421$2172 / 1797$.

Bremner, R. H. (1996). Giving: Charity and Philanthropy in History. New Jersey: Transaction Publishers.

Baeck, P. \& Bone, J. (2016). Crowdfunding Good Causes: Opportunities and Challenges for Charities, Community Groups and Social Entrepreneurs. Retrieved from nesta.org.uk.

Cheung, C. M., Lee, M. K., \& Rabjohn, N. (2008). The Impact of Electronic Word-of-mouth: The Adoption of Online Opinions in Online Customer Communities. Internet Research, 18(3), 229-247. https://doi.org/10.1108/10662240810883290. 
Cho, M., Bonn, M. A., \& Kang, S. (2014). Wine Attributes, Perceived Risk and Online Wine Repurchase Intention: The Cross-level Interaction Effects of Website Quality. International Journal of Hospitality Management, 43, 108-120. http://dx.doi.org/ 10.1016/j.ijhm.2014.09.002.

De Buysere, K., Gajda, O., Kleverlaan, R., \& Marom, D. (2012). A Framework for European Crowdfunding $1^{\text {st }}$ Edition. Available at: http://www.crowdfundingframework.eu/.

Featherman, M. S., \& Pavlou, P. A. (2003). Predicting E-Services Adoption: A Perceived Risk Facets Perspective. International Journal of Human-Computer Studies, 59(4), 451- 474. doi:10.1016/S1071-5819(03)00111-3.

Fornell, C., \& Larcker, D. F. (1981). Structural Equation Models with Unobservable Variables and Measurement Error: Algebra and Statistics. Journal of Marketing Research, 18(3), 382-388. DOI: $10.2307 / 3150980$.

Gerber, E. M., Hui, J. S., \& Kuo, P. Y. (2012). Crowdfunding: Why People Are Motivated to Participate, Northwestern University, Segal Design Institute, Technical Report No.2.

Golić, Z. (2014). Advantages of Crowdfunding as An Alternative Source of Financing of Small and Medium-sized Enterprises. Zbornik Radova Ekonomskog fakulteta u Istočnom Sarajevu, (8), 39-48. DOI: 10.7251/ZREFIS1408039G.

Hair, J. F., Black, W. C., Babin, B. J., \& Anderson, R. E. (2010). Multivariate Data Analysis (7th ed.). Englewood Cliffs: Prentice Hall.

Hasan, B. \& Dounia, B. (2013). Perceiving Successs Among Shariah Compliant Crowdfunding Social Entrepreneurs. Revue de Gestiab et d'Economie, 6(3), 264-293.

Hemer, J. (2011). A Snapshot on Crowdfunding (No. R2/2011). Arbeitspapiere Unternehmen und Region. Fraunhofer Institute for Systems and Innovation Research ISI http://publica.fraunhofer.de/documents/N-185931.html.

Hendratmi, A., Sukmaningrum, P. S., Ryandono, M. N. H., \& Ratnasari, R. T. (2019). The Role of Islamic Crowdfunding Mechanisms in Business and Business Development. Journal of Business and Economics Review, 4(1), 10-23.

Hendratmi, A., Ryandono, M. N. H., \& Sukmaningrum, P. S. (2019). Developing Islamic Crowdfunding Website Platform for Startup Companies in Indonesia. Journal of Islamic Marketing. https://doi.org/10.1108/JIMA-02-2019-0022.

Ho, H. Y., Lin, P. C., \& Lu, M. H. (2014). Effects of Online Crowdfunding on Consumers' Perceived Value and Purchase Intention. The Anthropologist, 17(3), 837-844. https://doi.org/10.1080/ 09720073.2014 .11891498$.

Ingenhoff, D., \& Koelling, A. M. (2009). The Potential of Web Sites as a Relationship Building Tool for Charitable Fundraising NPOs. Public Relations Review, 35(1), 66-73 DOI: 10.1016/j.pubrev.2008.09.023.

Joenssen, D., Michaelis, A., \& Müllerleile, T. (2014). A Link to New Product Preannouncement: Success Factors in Crowdfunding. Available at SSRN: http://dx.doi.org/10.2139/ssrn.2476841.

Kshetri, N. (2017). Informal Institutions and Internet-based Equity Crowdfunding. Journal of International Management, 24(3), 35-51. http://dx.doi.org/10.1016/j.intman. 2017.07.001.

Lam, P. T., \& Law, A. O. (2016). Crowdfunding for Renewable and Sustainable Energy Projects: An Exploratory Case Study Approach. Renewable and Sustainable Energy Reviews, 60, 11-20. 10.1016/j.rser.2016.01.046.

Lehner, O. M. (2013). Crowdfunding Social Ventures: A Model and Research Agenda. Venture Capital, 15(4), 289-311.

Lindenberg, S., \& Steg, L. (2007). Normative, Gain and Hedonic Goal Frames Guiding Environmental Behavior. Journal of Social issues, 63(1), 117-137. https://doi.org/10.1111/ j.1540-4560.2007.00499.x.

Marzban, S. Asutay, M. \& Boseli, A. (2014). Shariah Compliant Crowd Funding: An Efficient Framework for Entrepreneurship Development in Islamic Countries. Harvard Islamic Finance Forum. 
Mollick, E. R., \& Kuppuswamy, V. (2014). After the Campaign: Outcomes of Crowdfunding. UNC Kenan-Flagler Research Paper, (2376997). http://dx.doi.org/10.2139/ssm.2376997.

Morduch, J. (1999). The Microfinance Promise. Journal of Economic Literature, 37(4), 15691614. DOI: $10.1257 /$ jel.37.4.1569.

Mudambi, S. M., \& Schuff, D. (2010). Research Note: What makes a Helpful Online Review? A Study of Customer Reviews on Amazon. com. MIS quarterly, 185-200. https://dl.acm.org/doi/10.5555/2017447.2017457.

Nielsen, K. R. (2018). Crowdfunding through a Partial Organization Lens: The Co-dependent Organization. European Management Journal, 36(6), 695-707. https://doi.org/10.1016/ j.emj.2018.01.006.

OJK. Data Financial Technology di Indonesia. Retrieved from www.ojk.go.id. February 2020.

Pan, Y., \& Zhang, J. Q. (2011). Born Unequal: A Study of the Helpfulness of User-generated Product Reviews. Journal of Retailing, 87(4), 598-612. DOI: 10.1016/j.jretai.2011.05.002.

Park, D. H., \& Kim, S. (2008). The Effects of Consumer Knowledge on Message Processing of Electronic Word-of-mouth via Online Consumer Reviews. Electronic Commerce Research and Applications, 7(4), 399-410. DOI:10.1016/j.elerap.2007.12.001.

Powers, T. V. (2012). SEC Regulation of Crowdfunding Intermediaries Under Title III of the JOBS Act. Banking \& Financial Services Policy Report, 10(31), 1-7.

Ryandono, M. N. H. (2018). Fintech Waqaf: Solusi Permodalan Perusahaan Startup Wirausaha Muda. Jurnal Studi Pemuda, 7(2), 111-121. https://doi.org/10.22146/studipemudaugm.39347

Romānova, I., \& Kudinska, M. (2016). Banking and Fintech: A Challenge or Opportunity? In Contemporary issues in finance: Current challenges from across Europe. Emerald Group Publishing Limited, 98, 21-35. https://www.emerald.com/insight/publication/doi/10. 1108/S1569-3759201798

Schlosser, A. E. (2011). Can Including Pros and Cons Increase the Helpfulness and Persuasiveness of Online Reviews? The Interactive Effects of Ratings and Arguments. Journal of Consumer Psychology, 21(3), 226-239. https://doi.org/10.1016/j.jcps.2011.04.002.

Sen, S., \& Lerman, D. (2007). Why Are You Telling Me This? An Examination into Negative Consumer Reviews on the Web. Journal of Interactive Marketing, 21(4), 76-94. https:// doi.org/10.1002/dir.20090.

Seetharaman, A., Niranjan, I., Patwa, N., \& Kejriwal, A. (2017). A Study of the Factors Affecting the Choice of Investment Portfolio by Individual Investors in Singapore. Accounting and Finance Research, 6(3). https://doi.org/10.5430/afr.v6n3p153.

Sorenson, O., Assenova, V., Li, G. C., Boada, J., \& Fleming, L. (2016). Expand Innovation Finance via Crowdfunding. Science, 354(6319), 1526-1528 DOI: 10.1126/science.aaf6989.

Tu, T. T. T., Anh, D. P., \& Thu, T. T. H. (2018). Exploring Factors Influencing the Success of Crowdfunding Campaigns of Startups in Vietnam. Accounting and Finance Research, 7(2), 19-32.https://doi.org/10.5430/afr.v7n2p19.

Taha, T., \& Macias, I. (2014). Crowdfunding and Islamic Finance: A Good Match? In: Atbani F.M., Trullols C. (eds) Social Impact Finance. IE Business Publishing. London: Palgrave Macmillan. https://doi.org/10.1057/9781137372697_10.

United Nations Development Programme. (2017). Crowdfunding How Does It Work? When is it Feasible? 1-6. http://www.undp.org/content/sdfinance/en/home/solutions/templatefiche12.html.

Wahjono, S. I., Marina, A., \& Widayat. (2016). Critical Analysis of Crowdfunding to Finance SMES in Muslim Countries. Jurnal Balance, XIII(1), 1-13.

Wang, Z., \& Yang, X. (2019). Understanding Backer's Funding Intention in Reward Crowdfunding: An elaboration Likelihood Perspective. Technology in Society, 58. https://doi.org/10.1016/j.techsoc.2019.101149. 
Wijayanti, I., Herianingrum, S., \& Ryandono, M. N. H. (2020). Islamic Crowdfunding Mechanism to Answer Renewable Energy Investment Challenge in Indonesia. Test Engineering and Management, 83, 35963605.World Bank. 2013. Crowdfunding's Potential for the Developing World, InfoDev Washington: Finance and Private Sector Development Department.

Zhao, Q., Chen, C. D., Wang, J. L., \& Chen, P. C. (2017). Determinants of Backers' Funding Intention in Crowdfunding: Social Exchange Theory and Regulatory Focus. Telematics Inform, 34(1), 370-384, https://doi.org/10.1016/j.tele.2016. 06.006.

Zheng, H., Li, D., Wu, J., \& Xu, Y. (2014). The Role of Multidimensional Social Capital in Crowdfunding: A Comparative Study in China and US. Information and Management, 51(4), 488-496. https://doi.org/10.1016/j.im.2014.03.003. 